\title{
Cerebellar astrocytes co-express several ADP receptors. Presence of functional $\mathrm{P} \mathrm{Y}_{13}$-like receptors
}

\author{
Luz María G. Carrasquero*, Esmerilda G. Delicado*, Ana I. Jiménez, Raquel Pérez-Sen \& \\ M. Teresa Miras-Portugal \\ Departamento de Bioquímica, Facultad de Veterinaria, Universidad Complutense de Madrid, Madrid, Spain
}

Received 31 August 2004; accepted in revised form 21 October 2004

Key words: adenylate cyclase, ADP receptors, astrocytes, calcium, glial cells, nucleotide receptors, P2Y receptors

\begin{abstract}
Astrocytes exhibit a form of excitability based on variations of intracellular $\mathrm{Ca}^{2+}$ concentration in response to various stimuli, including ADP, ATP, UTP and dinucleotides. Here, we investigate the presence of the recently cloned ADPsensitive receptors, $\mathrm{P} 2 \mathrm{Y}_{12}$ and $\mathrm{P}_{2} \mathrm{Y}_{13}$ subtypes, which are negatively coupled to adenylate cyclase, in cerebellar astrocytes. We checked the effect of specific agonists, 2-methylthioadenosine diphosphate (2MeSADP) and ADP, on adenylate cyclase stimulation induced by isoproterenol. Both agonists significantly reduced the cAMP accumulation induced by isoproterenol. The inhibitory effect was concentration-dependent with $\mathrm{IC}_{50}$ values of $46 \pm 13$ and $23 \pm 14 \mathrm{nM}$ for 2MeSADP and ADP, respectively. The experiments were carried out in the presence of MRS-2179, a specific antagonist of $\mathrm{P} 2 \mathrm{Y}_{1}$ receptor, to avoid any contribution of this receptor. Using fura-2 microfluorimetry we also proved that astrocytes responded to $2 \mathrm{MeSADP}$ stimulations with calcium responses in the absence and also in the presence of MRS2179. Both effects, inhibition of adenylate cyclase and intracellular calcium mobilization, were not modified by $2 \mathrm{MeSAMP}$, an antagonist of $\mathrm{P}_{2} \mathrm{Y}_{12}$ receptor, suggesting that were mediated by $\mathrm{P} 2 \mathrm{Y}_{13}$-like receptors.
\end{abstract}

Abbreviations: 2MeSADP - 2-methylthioadenosine diphosphate; 2MeSAMP - 2-methylthioadenosine monophosphate; MRS-2179 - N6-methyl-2'-deoxyadenosine 3',5'-bisphosphate

\section{Introduction}

In recent years it has been demonstrated that astrocytes and other glial cells play a fundamental role in brain physiology by signalling to neurons and influencing their activity and vice versa. ATP and other nucleotides are involved in this neuron-glia interaction [1-3]. The extracellular actions of nucleotides are mediated by their interactions with specific membrane receptors, the P2-purinoceptors, subdivided into ionotropic P2X and metabotropic P2Y receptors [4]. Focusing on the metabotropic P2Y family, it comprises two structurally distinct subfamilies [5]. The first one is composed of $\mathrm{P} 2 \mathrm{Y}_{1}, \mathrm{P} 2 \mathrm{Y}_{2}, \mathrm{P}_{2} \mathrm{Y}_{4}, \mathrm{P} 2 \mathrm{Y}_{6}$ and $\mathrm{P} 2 \mathrm{Y}_{11}$ receptors, that exhibited different selectivity for adenine and uracile nucleotides, all exclusively coupled to phospholipase $\mathrm{C}$ pathway, except $\mathrm{P} 2 \mathrm{Y}_{11}$, which is also positively coupled to the cAMP pathway. The second subfamily includes $\mathrm{P} 2 \mathrm{Y}_{12}, \mathrm{P}_{2} \mathrm{Y}_{13}$ receptors, both selective

\footnotetext{
*These authors equally contributed to this work.

Correspondence to: Dr Esmerilda G. Delicado, Departamento de Bioquímica, Facultad de Veterinaria, Universidad Complutense, 28040, Madrid, Spain. Tel: +34-1-3943892; Fax: +34-1-3943909; E-mail: esmerild@vet.ucm.es
}

for ADP, and the UDP-glucose receptor, renamed $\mathrm{P}_{2} \mathrm{Y}_{14}$, which are all coupled to $G_{i}$. The identification of the $P 2 Y_{12}$ receptor has explained several ADP actions that were not mediated by $\mathrm{P}_{2} \mathrm{Y}_{1}$ receptors [6-9]. One interesting example is the case of platelets, in which ADP-induced aggregation requires both $\mathrm{P} 2 \mathrm{Y}_{1}$ and $\mathrm{P} 2 \mathrm{Y}_{12}$ activation. In fact, the $\mathrm{P} 2 \mathrm{Y}_{12}$ receptor is the target of antithrombotic drugs, such as clopidrogel and ATP derivatives, the AR-C compounds, such as ARC69931MX [8, 10-13]. Another example is the $\mathrm{G}_{\mathrm{i}}$-coupled $\mathrm{P} 2 \mathrm{Y}$ receptor distinct from $\mathrm{P} 2 \mathrm{Y}_{1}$, long known to exist in C6 glioma and B10 brain capillary endothelial cells, which has also been identified as $\mathrm{P} 2 \mathrm{Y}_{12}$ receptor [14-16]. Although to date there are not many data concerning the functionality of the $\mathrm{P} 2 \mathrm{Y}_{12}$ and $\mathrm{P} 2 \mathrm{Y}_{13}$ in neural cells, the high levels of expression found in brain suggests important roles in the nervous system [7, 17-20].

Our group has focused the investigation on the characterization of nucleotide receptors in cerebellum using purified cultures of neuronal and glial cells. We demonstrated that the two major neuronal types present in cerebellum, Purkinje cells and granule neurons, and astroglia expressed functional nucleotide receptors: Purkinje and granule neurons co-expressed ionotropic P2X and metabotropic P2Y nucleotide receptors and astrocytes 
only expressed functional P2Y nucleotide receptors [21-24]. Previous to the identification of the second subfamily of P2Y receptors the presence of $\mathrm{G}_{\mathrm{i} / \mathrm{o}}$-linked ADP receptors was detected in cerebellum, which was largely concentrated in the white matter $[25,26]$. The cloning of the new members prompted us to search their presence in the glial cells. The current study reveals the presence of functional $\mathrm{G}_{\mathrm{i} / \mathrm{o}}$-linked ADP receptors in cerebellar astrocytes and provides molecular and biochemical evidences to suggest that these receptors are $\mathrm{P}_{2} \mathrm{Y}_{13^{-}}$ like subtype.

\section{Materials and methods}

\section{Cultures of rat cerebellar type-1 astrocytes}

Type-1 astrocyte purified cultures were obtained from cerebellum of 7- to 8-day-old rats as previously described [27]. Cerebellar cells were dissociated by trypsin digestion and astrocytes purified by orbital shaken. They were grown until confluency in DMEM containing $10 \%(\mathrm{v} / \mathrm{v})$ fetal calf serum, $30 \mathrm{mM}$ glucose, $50 \mathrm{U} / \mathrm{ml}$ penicillin, $50 \mu \mathrm{g} / \mathrm{ml}$ streptomycin, $100 \mu \mathrm{g} / \mathrm{ml}$ kanamycin and $2.5 \mu \mathrm{g} / \mathrm{ml}$ amphotericin at $37{ }^{\circ} \mathrm{C}$ in a humidified atmosphere of $5 \%$ $\mathrm{CO}_{2} / 95 \%$ air. The type- 1 astrocytes, finally, were passaged by trypsinization with $0.05 \%$ trypsin and $0.002 \%$ EDTA in phosphate-buffered saline without added $\mathrm{Ca}^{2+}$ and $\mathrm{Mg}^{2+}$. Cells were plated in 24-well Petri dishes for cAMP determinations or over 15 -mm-diameter coverslips in 35$\mathrm{mm}$ Petri dishes at a density of 200,000 cells/well for microfluorimetric and immunocytochemistry experiments.

\section{Determinations of cAMP levels}

Cells were washed for $2 \mathrm{~h}$ at $37{ }^{\circ} \mathrm{C}$ in $1 \mathrm{ml}$ per well of Locke's solution (composition in $\mathrm{mM}$ : $\mathrm{NaCl}, 140 ; \mathrm{KCl}$, 4.5; $\mathrm{CaCl}_{2}, 2.5 ; \mathrm{KH}_{2} \mathrm{PO}_{4}, 1.2 ; \mathrm{MgSO}_{4}, 1.2 ;$ glucose, 5.5; HEPES (acid), 10; pH 7.4) and incubated for $30 \mathrm{~min}$ in the presence of $500 \mu \mathrm{M}$ rolipram. Then, cells were preincubated with $10 \mu \mathrm{M}$ MRS-2179 for $3 \mathrm{~min}$, previous to the stimulation with the agonists. Agonists were added for 3 $\mathrm{min}$, and the incubations were terminated by addition of $6 \%$ trichloroacetic acid. Cell lysates were centrifuged at $13,000 \mathrm{~g}$ for $10 \mathrm{~min}$ at $4{ }^{\circ} \mathrm{C}$ and the cAMP levels in the supernatants were measured using the enzyme-immunoassay kit from Amersham.

\section{Calcium imaging}

Cells attached to coverslips were washed with Locke's solution supplemented with $1 \mathrm{mg} / \mathrm{ml} \mathrm{BSA}$ and loaded with $5 \mu \mathrm{M}$ fura-2/AM for $45 \mathrm{~min}$ at $37^{\circ} \mathrm{C}$. The coverslip was placed in a small superfusion chamber and the cells were imaged through a NIKON TE-200 microscope with a Plan Fluor $20 \times / 0.5$. Emitted light was isolated by a dichroic mirror $(430 \mathrm{~nm})$ and a $510-\mathrm{nm}$ band pass filter (Omega Optical). The wavelength of the incoming light was selected with the aid of a monochromator (12-nm bandwidth, Perkin
Elmer Life Sciences) set at 340 and $380 \mathrm{~nm}$. Twelve-bit images were obtained using an Ultrapix 2000 Mono CCD camera controlled by Ultraview PC software. Exposure time was $50 \mathrm{~ms}$ and change in the wavelength of incoming light from 340 to $380 \mathrm{~nm}$ is carried out in less than $5 \mathrm{~ms}$. Time-course data represent the average light intensity in a small elliptical region within each cell. Background and autofluorescence components were subtracted at each wavelength and the $F_{340} / F_{380}$ ratio was calculated. $\left[\mathrm{Ca}^{2+}\right]_{\mathrm{i}}$ was derived from $F_{340} / F_{380}$ ratio using the equation's Grynkiewicz as previously described [21]. $R_{\max }$ and $R_{\min }$ parameters were obtained from an in vitro calibration performed by recording fluorescence from small droplets of fura-2 (free acid) dissolved in intracellular solution (in mM: $100 \mathrm{KCl}, 10 \mathrm{NaCl}, 1 \mathrm{MgCl}_{2}, 10$ MOPS and 1-2 $\mu \mathrm{M}$ fura-2, $\mathrm{pH} 7.0$ ) plus $2.5 \mathrm{mM} \mathrm{CaCl}_{2}$ (saturated $\mathrm{Ca}^{2+}$ ) or $2.5 \mathrm{mM}$ EGTA (zero $\mathrm{Ca}^{2+}$ ). The dissociation constant of fura-2 was assumed to be 224 nM. Drugs were applied to the cells by superfusion in Locke's solution at $37^{\circ} \mathrm{C}$.

\section{Immunocytochemical experiments}

For immunofluorescence assay, coverslips were fixed with 4\% PFA (w/v) for $15 \mathrm{~min}$, washed twice in PBS and incubated for $1 \mathrm{~h}$ in PBS containing 3\% BSA (w/v), $0.1 \%$ Triton X-100 (v/v), and 5\% normal goat serum (v/v). Cells were washed twice with PBS/BSA and incubated with the primary antibodies for $1 \mathrm{~h}$ at $37{ }^{\circ} \mathrm{C}$. Primary antibodies, diluted in PBS/BSA, recognized the specific rat proteins: mouse anti-glial fibrillar acid protein (GFAP, 1:200, Sigma), rabbit anti-P2 $\mathrm{Y}_{1}(1: 100$, Chemicon) and anti$\mathrm{P}_{2} \mathrm{Y}_{12}$ (1:50, Alomone). Cells were then washed three times and incubated for $1 \mathrm{~h}$ at $37^{\circ} \mathrm{C}$ with the appropriated secondary antibodies: Goat anti-mouse $\operatorname{IgG}$ fluorescein conjugated (1:1,000, Sigma) and goat anti-rabbit IgG rhodamine conjugated (1:500, Sigma). After this incubation, cells were washed three times and mounted following standard procedures with Prolong antifade medium (Molecular Probes). Controls of unspecific labeling were made in the same experimental conditions but the primary antibodies were replaced with the same volume of PBS/ BSA solution. Coverslips were viewed with a NIKON microscope equipped with a $60 \times 1.4$ oil objective and fluorescein/rhodamine filters.

\section{RT-PCR experiments}

Total RNA was isolated from astrocyte cultures from one passage and plated onto 35-mm-diameter culture dishes, using the RNeasy system (RNeasy extraction kit, Qiagen). Extracted RNA was routinely submitted to digestion with RNAse-free DNAse to eliminate traces of contaminating genomic DNA (DNA extraction kit, Qiagen), which could interfere in the PCR experiments. RNA was accurately measured using the sensitive fluorescent probe Ribogreen (RNA Quantitation Reagent, Molecular Probes).

cDNA was synthesized from $1 \mu \mathrm{g}$ total RNA using the MultiScribe Reverse Transcriptase (1.25 U/ml, Applied 
Biosystems), according to manufacturer instructions. Parallel RT reactions for each RNA sample were carried out in the absence of the reverse transcriptase enzyme, to evaluate the degree of genomic DNA contamination (-RT control). For PCR reactions, $2-5 \mu \mathrm{l}$ of the RT reaction product were amplified at $60{ }^{\circ} \mathrm{C}$ annealing using $0.625 \mathrm{U}$ of Ampli Taq Gold DNA polymerase (Applied Biosystems) and specific oligonucleotide primers for P2Y receptors. The following forward (Fw) and reverse (Rv) oligonucleotide primers obtained from rat cDNA sequences were used:

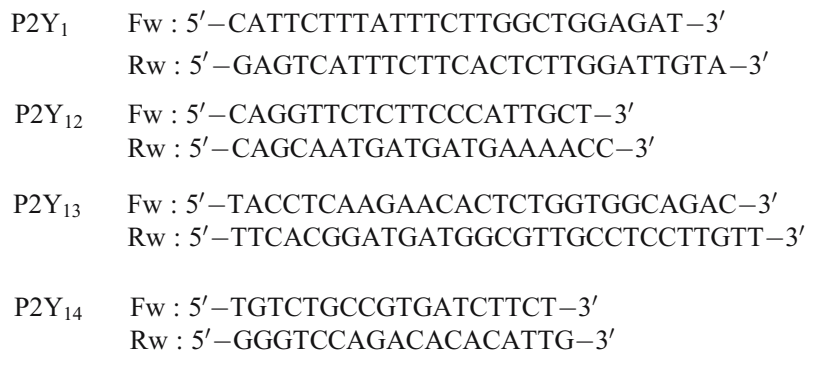

Parallel PCR reactions were carried out with RT products obtained from platelets, spleen and hippocampus as positive expression controls for $\mathrm{P} 2 \mathrm{Y}_{12}, \mathrm{P}_{2} \mathrm{Y}_{13}$ and $\mathrm{P} 2 \mathrm{Y}_{14}$ receptors, respectively.

\section{Statistical analysis}

Results are represented as the means \pm SE calculated from at least six experiments performed in duplicate from different cultures. Comparisons were made by one-way ANOVA, and Dunnett post-test analysis was only applied when a significant $(P<0.05)$ main effect was indicated by the ANOVA.

\section{Results}

To analyze the presence of $\mathrm{G}_{\mathrm{i}}$-linked ADP receptors in cerebellar astrocytes, we used several strategies, RT-PCR analysis for the detection of the mRNA codifying for $\mathrm{P} 2 \mathrm{Y}_{12}$ and $\mathrm{P} 2 \mathrm{Y}_{13}$ receptors, immunocytochemical studies to identify the corresponding proteins and biochemical and pharmacological approaches to prove their functionality.

\section{Expression of $m R N A$ for $P 2 Y_{1,12,13,14}$ receptors in cerebellar astrocyte cultures}

RT-PCR analysis showed that cerebellar astrocytes coexpressed several P2Y receptors of the ADP receptor family. Besides the $\mathrm{P} 2 \mathrm{Y}_{1}$ receptor, whose functionality in astrocytes has been previously demonstrated, $\mathrm{P}_{2} \mathrm{Y}_{12}$ and $\mathrm{P} 2 \mathrm{Y}_{13}$ mRNA were abundantly expressed in astrocytes in a similar extent to that found in platelets and spleen, respectively, in the same experimental conditions (Figure 1). The expression of the other member of the subfamily, the $\mathrm{P} 2 \mathrm{Y}_{14}$ receptor, was also detected. In all cases the specific bands of the PCR products were of the expected sizes and no signals were observed in control assays in the absence of templates.

\section{Inhibition of $c A M P$ production by $G_{i}$-linked $A D P$ receptors}

Based on the fact that cerebellar astrocytes possess $\beta$ adrenergic receptors coupled to adenylate cyclase activation, the presence and functionality of $\mathrm{G}_{\mathrm{i}}$-linked ADP receptors was investigated by analyzing the effect of specific agonists on cAMP production induced by isoproterenol. All these experiments were carried out in the presence of a specific antagonist of the $\mathrm{P} 2 \mathrm{Y}_{1}$ receptor, MRS-2179, to exclude any action of the agonists through this receptor. Adenosine deaminase was also added in the incubations to avoid any effect of the nucleoside produced by extracellular hydrolysis of nucleotides. In previous work we demonstrated that astrocytes possessed $\mathrm{A}_{2 \mathrm{~B}}$ adenosine receptors coupled to adenylate cyclase stimulation [27]. Figure 2 shows that co-stimulation of astrocytes with 2MeSADP or ADP and isoproterenol significantly reduced the isoproterenol-increased cAMP levels in a dose-dependent manner, reaching a maximum of $40 \%$ reduction at $10 \mu \mathrm{M}$ concentration. The $\mathrm{IC}_{50}$ values were $46 \pm 13$ and $23 \pm 14$ $\mathrm{nM}$ for 2MeSADP and ADP, respectively. The similar potency displayed by these agonists suggests that the ADP receptor that mediates this inhibition was a $\mathrm{P} 2 \mathrm{Y}_{13}$-like

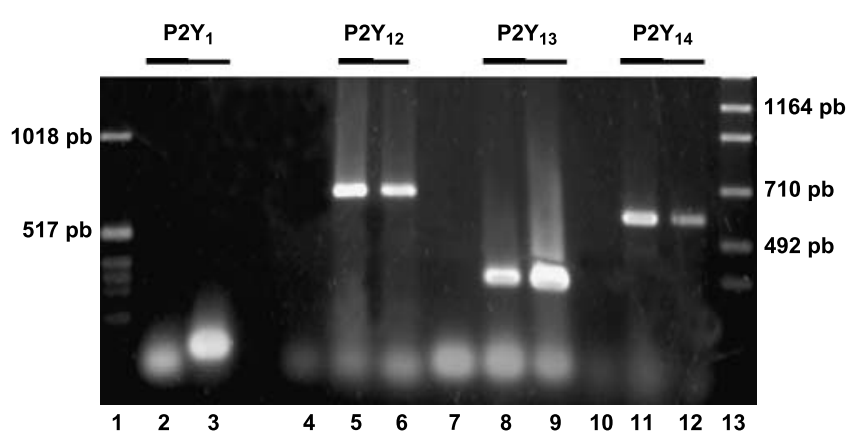

Figure 1. Expression of mRNAs for $\mathrm{P} 2 \mathrm{Y}_{1}, \mathrm{P}_{2} \mathrm{Y}_{12}, \mathrm{P} 2 \mathrm{Y}_{13}$ and $\mathrm{P} 2 \mathrm{Y}_{14}$ nucleotide receptors in cerebellar astrocyte cultures. Typical RT-PCR results obtained from three different cultures. PCR products for $\mathrm{P} 2 \mathrm{Y}_{1}, \mathrm{P}_{2} \mathrm{Y}_{12}, \mathrm{P} 2 \mathrm{Y}_{13}$ and $\mathrm{P} 2 \mathrm{Y}_{14}$ receptors in astrocytes are shown in lanes 3, 5, 8 and 11 , respectively. Expression controls were made using total RNA obtained from platelets for P2 $\mathrm{Y}_{12}$ (lane 6), spleen for P2Y 13 (lane 9) and hippocampus for $\mathrm{P}_{2} \mathrm{Y}_{14}$ receptors (lane 12). Besides the $\mathrm{H}_{2} \mathrm{O}$ controls performed in the absence of template are shown in lanes 2, 4, 7 and 10 . Band sizes were determined using RNA standards (lanes 1 and 13). 

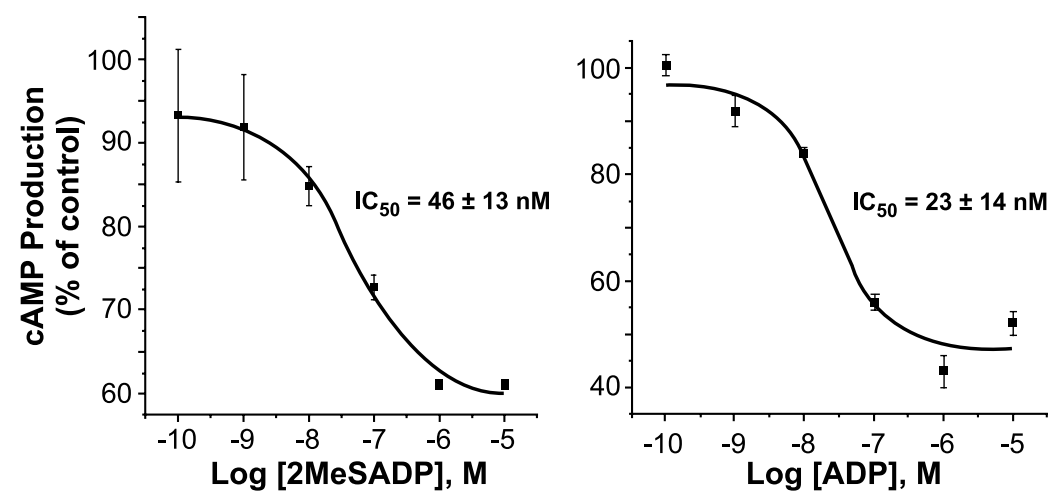

Figure 2. Identification of ADP receptors that inhibit isoproterenol-activated adenylate cyclase in cerebellar astrocytes. Astrocytes were preincubated with $10 \mu \mathrm{M}$ MRS-2179 previous to co-stimulation for $3 \mathrm{~min}$ with different concentrations of purinergic agonists (2MeSADP or ADP) and $10 \mu \mathrm{M}$ isoproterenol, and the cAMP accumulation was calculated as described in Materials and methods. Data were normalized with respect to the control for each experiment. Values are the means \pm SD of five experiments performed in triplicate. The logistic curves were fitted by non-linear regression.

receptor. To validate the involvement of the 'putative' $\mathrm{P}_{2} \mathrm{Y}_{13}$ receptors we examined the action of a $\mathrm{P} 2 \mathrm{Y}_{12}$ receptor antagonist, 2MeSAMP $[8,28]$. Since both agonists exhibited the same potency, and ADP can be hydrolyzed more quickly than 2MeSADP, 2MeSADP was used in the following experiments. Preincubation of astrocytes with the nucleotide derivative, 2-methylthioadenosine 5 '-monophosphate (2MeSAMP, $100 \mu \mathrm{M})$, did not revert the inhibition displayed by 2MeSADP (Figure 3). The diagram also shows that simple stimulation of astrocytes with 10 $\mu \mathrm{M}$ 2MeSADP or $100 \mu \mathrm{M}$ 2MeSAMP did not change basal cAMP levels. In addition, 2MeSAMP had not effect on cAMP accumulation stimulated by isoproterenol. Finally, it was tested whether the inhibition of adenylate cyclase by P2Y agonists was associated with a $G_{\alpha i}$ protein. For this purpose astrocytes were preincubated overnight with $100 \mathrm{ng} / \mathrm{ml}$ pertussis toxin previous to carry out cAMP determinations. This pretreatment completely abolished the inhibitory effect of 2MeSADP, indicating the involvement of a $G$ protein of the PTX-sensitive $\mathrm{G}_{\mathrm{i}} / \mathrm{G}_{\mathrm{o}}$ family (Figure 3).

\section{$2 M e S A D P$-induced calcium responses in cerebellar astrocytes}

Given that $\mathrm{P} 2 \mathrm{Y}_{13}$ receptor was also coupled to phospholipase $\mathrm{C}$ activation and the subsequent inositol phosphate production [7], we investigated its possible running in cerebellar astrocytes. Cells were challenged with $10 \mu \mathrm{M}$ 2MeSADP and single cell responses followed by microfluorimetry. As expected cells responded to 2MeSADP with rapid $\left[\mathrm{Ca}^{2+}\right]_{\mathrm{i}}$ transients (Figure 4). The $\Delta F_{340} / F_{380}$ were highly variable from cell to cell ranging from 0.022 to $0.088(0.051 \pm 0.002, n=224$ cells, corresponding to $\left[\mathrm{Ca}^{2+}\right]_{\mathrm{i}}$ increases of $360 \pm 45 \mathrm{nM}$ ). But, surprisingly most of tested cells also responded to 2MeSADP stimulations in the presence of the specific P2 $Y_{1}$ antagonist, MRS-2179, which reveals that other ADP-sensitive receptor was being activated. Although the magnitude of the calcium responses observed in the presence of MRS-2179 was very heterogeneous. We could distinguish three groups of cells: Cells that were nearly insensitive to MRS-2179 (38\% of cell population, population A), cells partially sensitive to MRS-2179 antagonism, which showed between $31 \%$ and $70 \%$ of control cell responses $(49 \%$ of tested cells, population B), and cells in which 2MeSADP responses were completely abolished by MRS-2179 (13\% of tested cells, population C).The same distribution pattern of calcium responses was obtained after preincubation with the two antagonists MRS-2179 and 2MeSAMP.

Finally, we also carried out immunocytochemistry experiments to detect the presence of $\mathrm{P}_{2} \mathrm{Y}_{12}$ protein. Figure 5 shows that there was no specific labeling of astrocytes with the anti-P2 $\mathrm{Y}_{12}$ receptor antibody, whereas, as expected, a specific staining was observed with the anti$\mathrm{P}_{2} \mathrm{Y}_{1}$ receptor antibody in the same experimental conditions. Positive controls for the $\mathrm{P}_{2} \mathrm{Y}_{12}$ receptor detection were made in platelets (results not shown).

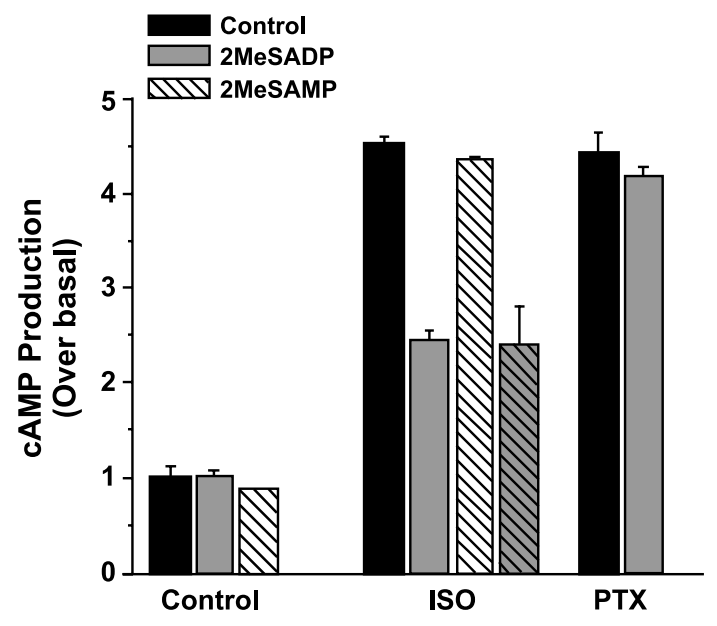

Figure 3. Effect of 2MeSAMP and pertussis toxin on the 2MeSADPinduced inhibition of cAMP production stimulated by isoproterenol in astrocytes. To check the effect of 2MeSAMP, cells were preincubated with $10 \mu \mathrm{M}$ MRS-2179 and $100 \mu \mathrm{M}$ 2MeSAMP for 3 min previous to costimulation with $10 \mu \mathrm{M}$ 2MeSADP and isoproterenol and cAMP production measured as described in Materials and methods. Where indicated, cells were stimulated with $10 \mu \mathrm{M} 2 \mathrm{MeSADP}$ or $100 \mu \mathrm{M}$ 2MeSAMP alone or in the presence of isoproterenol for $3 \mathrm{~min}$. To study the effect of pertussis toxin cells were treated overnight with $100 \mathrm{ng} / \mathrm{ml}$ pertussis toxin. Data were normalized with respect to the controls for each experiment. Values are the means \pm SD of four experiments performed in quadruplicate from different cultures. 


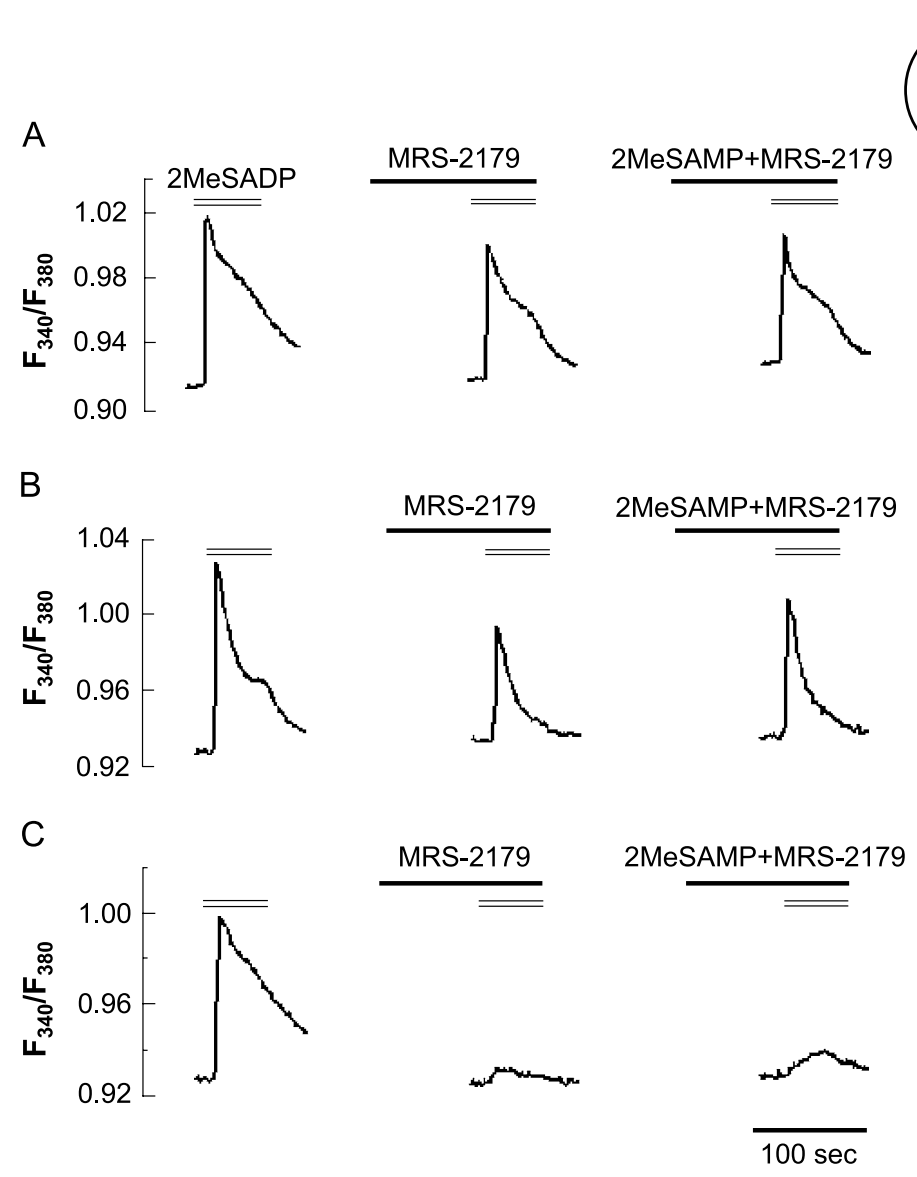

Figure 4. Calcium responses elicited by $2 \mathrm{MeSADP}$ stimulation in single cerebellar astrocytes. Cells were loaded with fura-2 and the time-course of fluorescence changes recorded from cells after stimulation with $10 \mu \mathrm{M}$ of the agonist for $40 \mathrm{~s}$ as described in Materials and methods. Where indicated, before cells were stimulated with 2MeSADP, they were preincubated for 3 min with $10 \mu \mathrm{M} \mathrm{MRS-2179}$ in the absence (middle recordings) or presence of $100 \mu \mathrm{M} 2 \mathrm{MeSAMP}$ (right recordings). Figure shows the calcium responses of three cells, which are representative of the cell subpopulations found with respect to their sensitivity to MRS-2179 antagonism (represented in the diagram, $n=300$ cells tested from three different cultures)
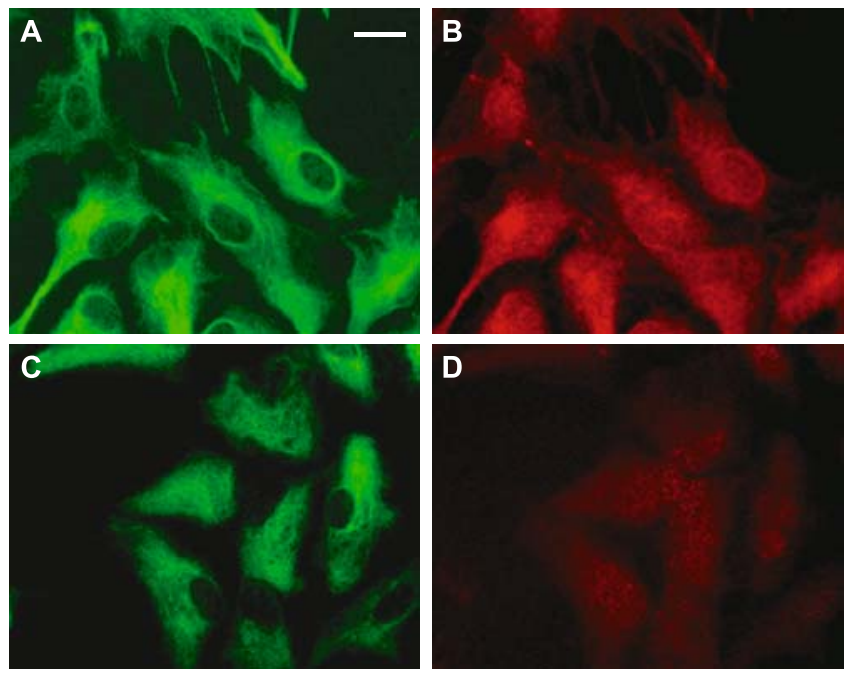

Figure 5. Fluorescence images of cerebellar astrocytes labelled with different antibodies. Panels A and C show specific anti-GFAP-FITC

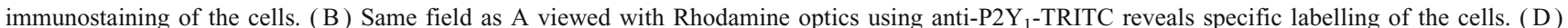
Same field as $\mathrm{C}$ viewed with Rhodamine optics using anti-P2 $\mathrm{Y}_{12}$-TRITC shows a negative immunolabelling. These images show the purity of the cultures, all the cells are identified as astrocytes. Bar $=20 \mu \mathrm{m}$. 


\section{Discussion}

In the present study we show the presence of functional $\mathrm{G}_{\mathrm{i}-}$ linked receptors in cultured astrocytes from rat cerebellum. The pharmacological profile of the analyzed responses to 2MeSADP and ADP suggests the involvement of $\mathrm{P}_{2} \mathrm{Y}_{13^{-}}$ like receptor subtype, which represents the first report of a functional $\mathrm{P} 2 \mathrm{Y}_{13}$-like receptor expressed in native cellular environment. The identification and characterization of $\mathrm{G}_{\mathrm{i}}$ linked receptors, such as $\mathrm{P} 2 \mathrm{Y}_{12}$ and/or $\mathrm{P}_{2} \mathrm{Y}_{13}$ in native tissues is quite difficult, particularly when they could be co-expressed with other P2Y subtypes, such as $\mathrm{P}_{2} \mathrm{Y}_{1}$. These three subtypes are ADP receptors with similar agonist profile (2MeSADP $\geq 2 \mathrm{MeSATP}>$ ADP $\geq$ ATP) and, in addition, there are no specific antagonists for each one of the subtypes. Whereas $\mathrm{P}_{2} \mathrm{Y}_{1}$ receptor can be selectively blocked by MRS-2179, the AR-C compounds described as specific antagonists of $\mathrm{P}_{2} \mathrm{Y}_{12}$ receptor can also act on some $\mathrm{P} 2 \mathrm{Y}_{13}[8,9,29-32]$. The pharmacological studies reported in the literature with the cloned $\mathrm{P}_{2} \mathrm{Y}_{12}$ and $\mathrm{P}_{2} \mathrm{Y}_{13}$ receptors revealed that they could be distinguished by the relative potency of $2 \mathrm{MeSADP}$ and ADP. At the platelet $\mathrm{P}_{2} \mathrm{Y}_{12}$ and brain $\mathrm{P} 2 \mathrm{Y}_{12}$ like receptor $2 \mathrm{MeSADP}$ is more potent than ADP (two or three orders of magnitude) and clearly differs from the $\mathrm{P}_{2} \mathrm{Y}_{13}$ at which both agonists are nearly equipotent $[8,28,30,31]$. In cerebellar astrocytes 2MeSADP and ADP exhibited similar potency in decreasing cAMP accumulation induced by isoproterenol. Although it is not accurate to compare the relative potency of agonists described for the different cloned receptors, the $\mathrm{IC}_{50}$ values reported here were very similar to those described for the human and mouse $\mathrm{P}_{2} \mathrm{Y}_{13}$ receptors $\left(\mathrm{IC}_{50}=13 \mathrm{nM}\right)$. The values are critically dependent on the experimental conditions, such as expression levels of receptor in the different cell lines and effector system assessed, cAMP and/or inositol phosphate production, fluorimetric imaging plate reader assays, binding of radiolabelled agonists, etc. The recent cloning and pharmacological characterization of $\mathrm{P}_{2} \mathrm{Y}_{13}$ receptor from rat tissues has revealed that ADP is two to three times more potent than 2MeSADP on this receptor, which agrees with our results [32].

Others findings that supported the involvement of a P2 $\mathrm{Y}_{13}$-like receptor are that 2MeSADP effects, both the repression of cAMP levels and the calcium responses recorded in the presence of MRS-2179, were not reversed by $2 \mathrm{MeSAMP}$, which is a selective antagonist of $\mathrm{P}_{2} \mathrm{Y}_{12}$ receptor. 2MeSAMP $(10$ and $50 \mu \mathrm{M})$ completely abolished the ADP and 2MeSADP effects mediated by the P2Y 12 receptor [8]. In addition, we have not detected the presence of $\mathrm{P} 2 \mathrm{Y}_{12}$ protein by immunocytochemistry using a specific antibody for the $\mathrm{hP} 2 \mathrm{Y}_{12}$, whereas the presence of $\mathrm{P} 2 \mathrm{Y}_{1}$ protein was confirmed in the same experimental conditions. These negative results supported the involvement of another $\mathrm{G}_{\mathrm{i}}$-linked ADP receptor. Although we cannot exclude the possibility that $\mathrm{P}_{2} \mathrm{Y}_{12}$ receptor could be coexpressed in some cells in a very low quantity below detection limit in our experimental conditions. It is interesting to take into account that the detection of mRNA does not always correlate with the presence of the corresponding protein. In this sense, we have also found by RT-PCR bands that corresponded to mRNA for some $\mathrm{P} 2 \mathrm{X}$ subunits $\left(\mathrm{P} 2 \mathrm{X}_{1}, \mathrm{P} 2 \mathrm{X}_{3}\right.$ and $\left.\mathrm{P} 2 \mathrm{X}_{4}\right)$ in our astrocyte cultures (results not shown) but we have not detected any ionotropic nucleotide responses. In contrast to these findings, the presence of ionotropic P2X receptors in astrocytes from other brain areas has been demonstrated [33-35]. This heterogeneity might be related to the need to regulate the different neurotransmission types.

To conclude, the present study reveals that cerebellar astrocytes possess at least two specific ADP receptors, which can be simultaneously activated at nanomolar concentrations of the nucleotide, $\mathrm{P}_{2} \mathrm{Y}_{1}$ and $\mathrm{P} 2 \mathrm{Y}_{13}$-like receptors, coupled to phospholipase $\mathrm{C}$ stimulation and adenylate cyclase inhibition, respectively (Figure 6). The question that arises is: What is the function of these receptors in astrocytes? As previously mentioned, it is clearly demonstrated that $\mathrm{P} 2 \mathrm{Y}_{1}$ and $\mathrm{P} 2 \mathrm{Y}_{12}$ cooperate to induce

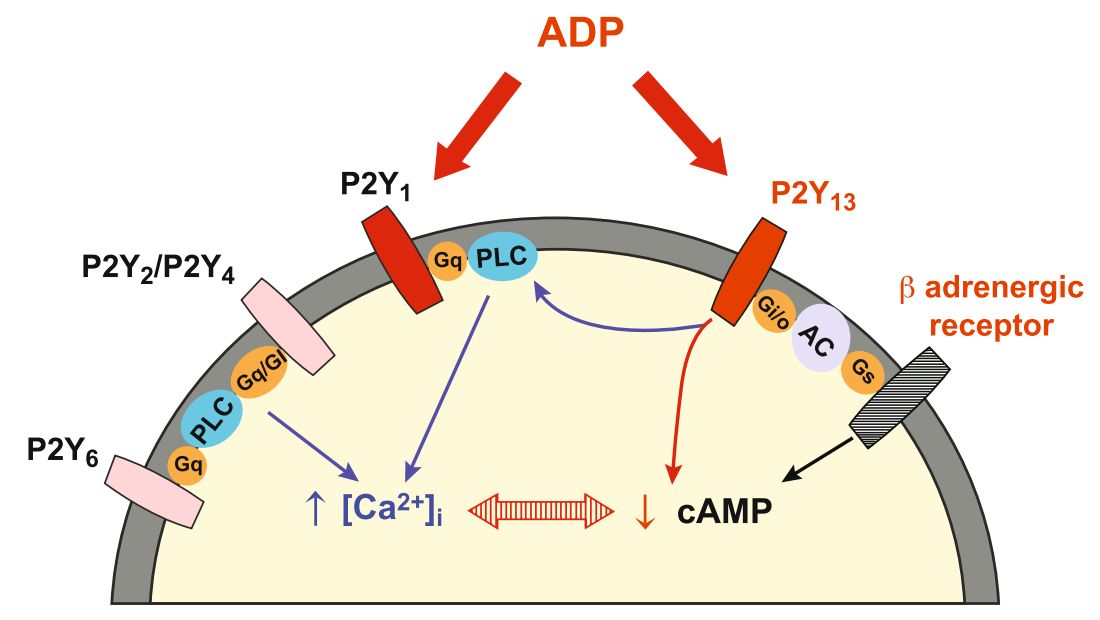

Figure 6. Schematic representation of P2Y nucleotide receptors present in cerebellar astrocytes. Astrocytes coexpressed several P2Y receptors that can be selectively stimulated by adenine and uracile nucleotides. ADP would interact with $\mathrm{P}_{2} \mathrm{Y}_{1}$ and $\mathrm{P} 2 \mathrm{Y}_{13}$-like receptors triggering two intracellular signaling cascades, intracellular calcium mobilization and decreasing cAMP production. 
ADP-induced platelet aggregation, a similar cooperation between $\mathrm{P}_{2} \mathrm{Y}_{1}$ and $\mathrm{P} 2 \mathrm{Y}_{13}$-like receptor could be take place in astrocytes to control metabolism, proliferation, differentiation or even apoptosis depending on cellular environment or otherwise function independently. The fact that $\mathrm{P} 2 \mathrm{Y}_{13}$-like receptor stimulation also induced calcium responses might suggest that $\mathrm{P} 2 \mathrm{Y}_{13}$ would substitute $\mathrm{P}_{2} \mathrm{Y}_{1}$ receptor, when the later was in inactive state.

\section{Acknowledgements}

This work was supported by grants from Ministerio de Ciencia y Tecnología (BFI2002-03626) and Comunidad Autónoma de Madrid (CAM 88.5/0004.1/2003). L.M.G. Carrasquero is a fellow from Ministerio de Educación.

\section{References}

1. Neary JT, Rathbone MP, Cattabeni F et al. Trophic actions of extracellular nucleotides and nucleosides on glial and neuronal cells. Trends Neurosci 1996; 19: 13-8.

2. Araque A, Carmignoto G, Haydon PG. Dynamic signalling between astrocytes and neurons. Annu Rev Physiol 2001; 63: 795-813.

3. Nedergaard M, Ranson B, Goldman SA. New roles for astrocytes: Redefining the functional architecture of the brain. Trends Neurosci 2003; 26: 523-30.

4. Ralevic V, Burnstock G. Receptor for purines and pyrimidines Pharmacol Rev 1998; 50: 413-92.

5. Abbracchio MP, Boeynaems JM, Barnard EA et al. Characterization of the UDP-glucose receptor (re-named here the $\mathrm{P}_{2} \mathrm{Y}_{14}$ receptor) adds diversity to the P2Y receptor family. Trends Pharmacol Sci 2003; 24: $52-5$.

6. Chambers JK, Macdonald LE, Sarau HM et al. A G protein-coupled receptor for UDP-glucose. J Biol Chem 2000; 275: 10767-71.

7. Communi D, González NS, Detheux M et al. Identification of a novel human ADP receptor coupled to $\mathrm{G}_{\mathrm{i}}$. J Biol Chem 2001; 276: 41479-85.

8. Hollopeter G, Jantzen H-M, Vincent D et al. Identification of the platelet ADP receptor targeted by antithrombotic drugs. Nature 2001; 409: 202-7.

9. Zhang FL, Luo L, Gustafson E et al. ADP is the cognate ligand for the orphan G protein-coupled receptor SP1999. J Biol Chem 2001; 276: 8608-15.

10. Humphries RG. Pharmacology of AR-69931MX and related compounds: From pharmacologicals tools to clinical trials. Haematologica 2000; 85: 66-72.

11. Savi P, Labouret $C$, Delesque $N$ et al. P2 $Y_{12}$, a new platelet ADP receptor, target of clopidrogrel. Biochem Biophys Res Commun 2001; 283: 379-83.

12. André $\mathrm{P}$, Delaney $\mathrm{SM}, \mathrm{La}$ Rocca $\mathrm{T}$ et al. $\mathrm{P} 2 \mathrm{Y}_{12}$ regulates platelet adhesion/activation, thrombus growth, and thrombus stability in injured arteries. J Clin Invest 2003; 112: 398-406.

13. Haseruck N, Erl W, Pandey D et al. The plaque lipid lysophosphatidic acid stimulates platelet activation and platelet-monocyte aggregate formation in whole blood: Involvement of $\mathrm{P}_{2} \mathrm{Y}_{1}$ and $\mathrm{P}_{2} \mathrm{Y}_{12}$ receptors. Blood 2004; 103(7): 2585-92.

14. Jin J, Tomlinson W, Kirk IP et al. The C6-2B glioma cell P2 $\mathrm{Y}_{\mathrm{AC}}$ receptor is pharmacologically and molecularly identical to the platelet P2 $Y_{12}$ receptor. Br J Pharmacol 2001; 133: 521-8.

15. Czakowski R, Lei L, Sabala P, Baranska J. ADP-evoked phospholipase $\mathrm{C}$ stimulation and adenylyl cyclase inhibition in glioma C6 cells occur through two distinct nucleotide receptors, $\mathrm{P} 2 \mathrm{Y}_{1}$ and P2Y 12 . FEBS Lett 2002; 513: 179-83.

16. Simon J, Filippov AK, Goransson $\mathrm{S}$ et al. Characterization and channel coupling of the P2Y(12) nucleotide receptor of brain capillary endothelial cells. J Biol Chem 2002; 277(35): 31390-400.

17. Kulick MB, von Kügelgen I. P2Y-receptors mediating an inhibition of the evoked entry of calcium through N-type calcium channels at neuronal processes. J Pharmacol Exp Ther 2002; 303: 520-6.

18. Unterberger U, Moskvina $\mathrm{E}$, Scholze $\mathrm{T}$ et al. Inhibition of adenylyl cyclase by neuronal P2Y receptors. Br J Pharmacol 2002; 135: 673-84.

19. Queiroz G, Talaia C, Goncalves J. ATP modulates noradrenaline release by activation of inhibitory $\mathrm{P} 2 \mathrm{Y}$ receptors and facilitatory $\mathrm{P} 2 \mathrm{X}$ receptors in the rat vas deferens. J Pharmacol Exp Ther 2003; 307: 809-15.

20. Wirkner K, Schweigel J, Gerevich Z et al. Adenine nucleotides inhibit recombinant $\mathrm{N}$-type calcium channels via $\mathrm{G}$ protein-coupled mechanisms in HEK 293 cells; involvement of the P2Y 13 receptortype. Br J Pharmacol 2004; 141: 141-51.

21. Mateo J, García-Lecea M, Miras-Portugal MT, Castro E. $\mathrm{Ca}^{2+}$ signals mediated by P2X-type purinoceptors in cultured cerebellar Purkinje cells. J Neurosci 1998; 18: 1704-12.

22. García-Lecea M, Delicado EG, Miras-Portugal MT, Castro E. P2X2 characteristics of the ATP receptor coupled to $\mathrm{Ca}^{2+}$ increase in cultured Purkinje neurons from neonatal rat cerebellum. Neuropharmalology 1999; 38: 699-706.

23. Jiménez AI, Castro E, Communi D et al. Coexpression of several types of metabotropic nucleotide receptors in single cerebellar astrocytes. J Neurochem 2000; 75: 2071-9.

24. Hervás C, Pérez-Sen R, Miras-Portugal MT. Coexpression of functional P2X and P2Y nucleotide receptors in single cerebellar granule cells. J Neurosci Res 2003; 73: 384-99.

25. Laitinen JT, Uri A, Raidaru G, Miettinen R. $\left.{ }^{35} \mathrm{~S}\right] \mathrm{GTP} \gamma \mathrm{S}$ autoradiography reveals a wide distribution of $\mathrm{G}_{\mathrm{i} / \mathrm{o}}$-linked ADP receptors in the nervous system: Close similarities with the $\mathrm{P} 2 \mathrm{Y}_{\mathrm{ADP}}$ receptor. $\mathrm{J}$ Neurochem 2001; 77: 505-18

26. Vasiljev KS, Uri A, Laitinen JT. 2-Alkylthio-substitute platelet $\mathrm{P} 2 \mathrm{Y}_{12}$ receptor antagonists reveal pharmacological identity between the rat brain $\mathrm{G}_{\mathrm{i}}$-linked $\mathrm{ADP}$ receptors and $\mathrm{P} 2 \mathrm{Y}_{12}$. Neuropharmacology 2003; 45: 145-54.

27. Jiménez AI, Castro E, Mirabet M et al. Potentiation of ATP calcium responses by $\mathrm{A}_{2 \mathrm{~B}}$ receptors stimulation and other signals coupled to Gs proteins in type-1 cerebellar astrocytes. Glia 1999; 26: 119-28.

28. Takasaki J, Kamohara M, Saito T et al. Molecular cloning of the platelet $\mathrm{P}_{2} \mathrm{~T}_{\mathrm{AC}} \mathrm{ADP}$ receptor: Pharmacological comparison with another ADP receptor, the $\mathrm{P}_{2} \mathrm{Y}_{1}$ receptor. Mol Pharmacol 2001; 60: 423-39.

29. Boyer JL, Mohanram A, Camaioni E et al. Competitive and selective antagonists of $\mathrm{P} 2 \mathrm{Y}_{1}$ receptors by $\mathrm{N}^{6}$-methyl $2^{\prime}$-deoxyadenosine $3^{\prime}, 5^{\prime}$ biphosphate. Br J Pharmacol 1998; 124: 1-3.

30. Zhang FL, Luo L, Gustafson $\mathrm{E}$ et al. $\mathrm{P} 2 \mathrm{Y}_{13}$ : Identification and characterization of a novel Goi -coupled ADP receptor from human and mouse. J Pharmacol Exp Ther 2002; 301: 705-13.

31. Marteau F, Le Poul E, Communi D et al. Pharmacological characterization of the human $\mathrm{P}_{2} \mathrm{Y}_{13}$ receptor. Mol Pharmcol 2003; 64: 104-12.

32. Fumagalli M, Trincavelli L, Lecca D et al. Cloning, pharmacological characterisation and distribution of the rat G-protein-coupled $\mathrm{P}_{2} \mathrm{Y}_{13}$ receptor. Biochem Pharmacol 2004; 68: 113-24.

33. Franke H, Grosche J, Schadlich $\mathrm{H}$ et al. $\mathrm{P} 2 \mathrm{X}$ receptor expression on astrocytes in the nucleus accumbens of rats. Neuroscience 2001; 108: 421-9.

34. Kukley M, Barden JA, Steinhauser C, Jabs R. Distribution of P2X receptors on astrocytes in juvenile rat hippocampus. Glia 2001; 36 : 11-21.

35. Fumagalli M, Brambilla R, D’Ambrosi N et al. Nucleotide-mediated calcium signaling in rat cortical astrocytes: Role of P2X and P2Y receptors. Glia 2003; 43: 218-30. 